\title{
ECONOMIC AND EDUCATIONAL DEVELOPMENTS IN MALTA
}

SU UBJECT to the approval of Parliament, the British Government agreed with the Government of Malta on February 27 to contribute a total of $£ 6,077,000$ to the Maltese budget for 1957-58, of which $£ 899,000$ is towards the ordinary budget deficit, $£ 540,000$ for war damage compensation and $£ 4,638,000$ to the capital budget, including war damage grants and Colonial Development and Welfare grants. 'This total compares with $\mathfrak{f 2 , 7 0 5 , 3 1 8}$ for $1954-55, £ 4,382,392$ for $1955-56$ and $£ 5,433,778$ for $1956-57$, and the financial statement for $1957-58$ issued to the Legislative Assembly on March 8, 1957, pays tribute to Britain's growing help to the people of Malta in their economic difficulties.

Referring to the increasing tempo with which the basic facilities for economic development are being strengthened, the Statement points out that the cost of extracting and storing additional water supplies is not greatly different from that in the United Kingdom, but there is much leeway to be made up for years of under-investment. For 1957-58, estimated expenditure on water development is $£ 1,020,630$,

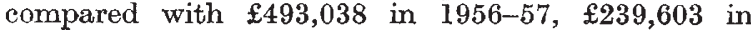
$1955-56$ and $£ 150,466$ in $1954-55$, and schemes are in hand which could give an increase of just over 50 per cent on the present daily production of nearly 7 million gallons.

The harbour development project is estimated to cost about $£ 2$ million, of which $£ 295,000$ is expected to be spent in 1957-58, but it will be two years before the first deep-water berths come into operation, and in the meantime the Malta Tug and Lighter Co. is to purchase, under a Government guarantee, nine to twelve steel lighters, designed to Government specification, to relieve congestion. Good progress is being made with the change-over in the electricity distribution system, which is now scheduled for completion by December 1958 instead of April 1960 . The old coal-gas plant is being replaced by a modern catalytic oil-gas plant, and up to 5,000 consumers will be supplied from a liquid petroleum bottling plant at a capital cost for both projects estimated at $£ 231,000$.

In technical education 200 boys will be admitted to the new Boys' Technical Sehool at Kordin in September 1957 and 200 annually thereafter until the complement of 1,000 is reached, while work will commence on two new technical schools in 1957-58, one for boys and one for girls, and the new Technical School and Lyceum should be completed in 1957-58. It is hoped shortly to introduce a two-year course for emigrants at the Marsa Industrial Training Centre and to arrange with the United Kingdom Ministry of Labour to place the trainees in factories whero they will get practical experience of operating modern machinery and using modern techniques.

Industrial development was seriously set back by the Suez crisis ; but the Maltese Government hopes to overcome somo of the credit difficulties with its proposed 'Aids to Industry' Bill, and in the 1957-58 estimates $£ 30,000$ is earmarked for an industrial estate and $£ 45,000$ for loans and grants to new industries. The considerable assistance now being given to farmers and fishermen is stemming the exodus from these industries: provision for fisheries has been increased to $£ 163,520$ and for agriculture to $£ 421,466$. Great emphasis is being placed on agricultural education and training, and next year trainees will be sent to agricultural colleges in the United Kingdom with a view of eventually replacing the overseas experts at present helping Malta. The road programme for 1957-58 concentrates on roads which can be justified on economic grounds, besides giving employment to unskilled labourers, and the estimate is for $£ 382,100$ compared with $£ 442,887$ in 1956-57.

In reviewing the revised estimates for 1956-57, which show an estimated deficit of $£ 692,983$ in the

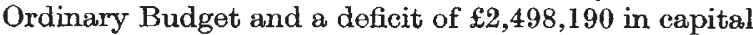
expenditure, the Statement notes that the contribution from the United Kingdom includes $£ 1,674,392$ for war damage and reconstruction, $£ 347,049$ from Colonial Development and Welfare grants, and $£ 156,000$ towards emigration. Tribute is paid to the work of sixty-seven overseas experts in implementing new development schemes, but the Maltese Government is determined to improve the opportunities available for capable Maltese, and since March 1955 sixty-five Government employees have been seconded for training abroad. During 1957-58 a further eightyeight will attend courses in English universities and other seats of learning, of whom thirty will be from the Ministry of Education, seventeen from the Ministry of Agriculture, sixteen from the Ministry of Health and eight from the Ministry of Works.

Finally, the Statement concludes that the flow of new capital should shortly make it possible for every citizen to contribute much more towards the welfare of the State than was possible in the past, and the Maltese people should no longer continue to invest their entire savings abroad. It should become feasible to launch local Government-backed bonds which could be utilized to set up locel industries in Malta.

\section{THE CRICHTON-MILLER REPORT}

$A$ T the end of 1956, Mr. D. Crichton-Miller, headmaster of Fettes College, Edinburgh, visited Maltia on the invitation of the Prime Minister, the Hon. Dom Mintoff, "to review the progress made in the last 21 months in the provision of education; to consider future developments, particularly in higher and technical education; and to suggest ways in which these developments can be effectively related to the economy of Malta". Mr. CrichtonMiller has since submitted his report (Office of the Minister of Education, Valetta, Malta).

Malta is facing many important problems coupled with the proposals for changes in her political status within the British Commonwealth. In spite of attempts to encourage her younger people to emigrate and to persuade countries such as the United States, Australia and New Zealand to accept more Maltese, the inhabited islands, which comprise Malta, 
Gozo and Comino, are some of the most densely populated in the world. (The inhabited islands are 121 square miles in extent, and these house a population of 314,000 .) Malta will be profoundly affected by the proposed cuts in the British Armed Forces, and she has already been warned of a reduction in civilian personnel in her Dockyard, which has, hitherto, been her main economic prop. Owing to the nature of the islands and the seas around, agriculture and fisheries-her main industries-are difficult, and forestry presents problems unfamiliar to those used to more fertile and deeper soils. The present Government is making considerable efforts to get more industries started-sponsored either by the State or by private enterprise. Education in this densely populated area is therefore of paramount importance, not only to Malta herself but also to the Commonwealth.

It may surprise some people to learn that compulsory education was not introduced into Malta until after the Second World War (March 1946); but the Crichton-Miller Report reveals that great strides towards improvements have been taken since then, especially by the present Government. Naturally, considerable difficulties were met in implementing the policy of compulsory education, especially during its initial stages. 'This was due mainly to the rising child population, which was increasing at the rate of a thousand a year in an area of a total population of 314,000 . Indeed, up to so recently as September 1954, only 561 out of a total of 1,777 primary school classes were receiving fulltime education in their own class-rooms.

\section{Primary Education}

A very determined scheme which was begun in March 1955 saw the eradication of all part-time work -as the Report indicates, "a truly remarkable achievement". Credit for this must be given to the present Government of Malta and especially to the Minister of Education, the Hon. Agatha Barbara, and to the Director of Education, Mr. J. P. Vassallo.

Mr. Crichton-Miller expresses his conviction that the children are now housed in such a way that teaching can be carried out with almost the maximum efficiency. This, coupled with the Government's most recent Financial Statement that the building of new schools is to be accorded priority, must be gratifying to those most closely concerned. There are now 120 government primary schools and many private elementary schools. At present there are about 53,000 children in the government schools, and soon the authorities will be faced with the problem of distributing annually about 10,000 children who, at the age of 11-12 years, have completed a comprehensive course of primary education. It seems, however, that the Government's prodigious efforts at improving educational opportunities and standards are much favoured by children who are by nature very intelligent, and whose manners and discipline are above average (due to home and church influences), and by parents who are cooperative.

The children are admitted to the primary schools at the age of six, and the Report gives cogent reasons for not reducing this to five, as in Great Britain. The Report also advocates a short junior secondary course of 2-3 years duration in the present primary schools proper. Such a course, followed by a cer. tificate examination in English and possibly arithmetic, might prove helpful to such school leavers when applying for work. Children may leave school at the age of fourteen, and the Report does not support the idea that the school-leaving age should be raised to fifteen, though pupils should be allowed to stay on at school on a voluntary basis.

A 'compulsory control examination' at the end of the primary school age is recommended. This would correspond to the so-called 'eleven-plus' examination in Britain; but a two-year range is suggested for Malta. Thus the bright child would gain early promotion, whereas the slower child would get a second chance. Following this examination, children would be drafted to secondary grammar, secondary technical or secondary clerical courses, or they would take the 'short secondary' course mentioned above. Thus the present special arrangements for the preparation of Dockyard candidates would be eliminated-arrangernents which Mr. Crichton-Miller, in any event, deplores. Moreover, if a control examination is introduced, it would be unnecessary to include in the primary syllabus any special training of candidates for the Lyceum in Valetta.

\section{Higher and Technical Education}

Considerable developments have recently been made in secondary education, and new training colleges are being developed for which the Government has obtained financial assistance from various sources. At present there are six secondary schools (one of them preparatory) and two technical schools, apart from the Lyceum. New buildings, especially for the Lyceum in Valetta, are in an advanced stage.

The general aim is to provide for 5,000 pupils in the Lyceum and a girls' school (both of grammar school status), senior and junior technical schools and a girls' clerical college. These will be in Malta, and a similar provision on a smaller scale will be made in Gozo. The Report maintains that this aim is not too ambitious, provided that the primary schools supply the candidates of the requisite standard.

The main problem here is the provision of a sixth form, for staff will be required, and the parents will have to be persuaded to use it. In this connexion, $a$ great deal depends on the Royal University of Malta, because at present its students on entry have not done the kind of post-certificate course with twoadvanced-level subjects as is demanded by most universities. It is claimed that if the University demanded a sixth-form standard in its freshmen, then parents would eventually recognize the value of such a sixth form.

If and when a sixth form becomes established in the secondary schools, the main problem to be faced will be its content. In the past, seience subjects have been neglected. This is ascribed by some to the shortage of science teachers. But according to the Report, this is not the only reason, because the children of Malta go in for the study of languages more than do those of any other country in Europe; in fact, it is not unusual to find a pupil in a grammar school studying as many as five languages. In view of this, Mr. Crichton-Miller goes so far as to suggest that in the new science sixth forms, cultural subjects should be virtually excluded if the production of high-class scientists and technologists is not to be 
prejudiced at university entrance-level. It appears, therefore, that the only institution in Malta which could maintain a comprehensive sixth form offering science and arts subjects, as understood in the average large British grammar school, would be the Lyceum. The Report also suggests that the other secondary schools should specialize in their sixth forms in either arts or sciences, or languages, ete.

The suggested 'clerical' grammar schools will cater for children who do not intend proceeding to the University, so these schools will have no sixth form. Their certificate examination will be at the ordinary level and will embrace more commercial subjects. Nothing has so far been done towards the development of such schools.

The supply of skilled craftsmen and technicians is being taken into careful consideration; in fact, even at the level of ordinary secondary education, there are to be schools having a technical bias. Some pupils will drop out of such schools at the age of fourteen, and go straight to trade apprenticeships, whereas others will proceed to a senior technical school. A polytechnic school is also being planned.

The secondary school-leaving age is to be 15-17. Most of these school leavers will go straight into employment, though some of them will continue part-time studies, mainly on the technical side. 'The rest will continue their education (1) overseas; (2) at a teachers' training college; (3) at the polytechnic (when ready); or (4) at the Royal University of Malta. Those who proceed to a British or other university will be ensured of a satisfactory advanced education. The proposed scheme for a polytechnic is still uncertain, but will no doubt develop as the demand grows.

The Report envisages about 150 students wishing to gain admission to the Royal University of Malta; but, alas, the University is at present in no position to cope with such a demand. In fact, it is suggested in the Report that the University should be subjected to complete re-organization if it is to play its part in the quickly developing educational scheme in Malta. It is not possible at this stage to make any constructive suggestions, though the Report does hint at the need for extra-mural advice. The University is autonomous, but looks mainly to the Government for its funds, so it is only natural that the Government should wish to know what it is paying for*.

It is obvious from the Crichton-Miller Report that the main shortcomings in education in Malta lie in the lack of sixth forms in the secondary schools and in the general organization of the University. It is curious that the development of education in Malta since school education became compulsory is starting from the primary schools, whereas in Britain and elsewhere it has been the universities which originally set the pace.

\section{Aims and Objectives}

The aim of the present large-scale programme of educational development in Malta is threefold: ( 1 ) to give the people one of the fundamental benefits of

* It is encouraging to learn that the Government and the University, with the assistance of the Inter-University Council for Higher Education Overseas, are to form a mission comprised of certain authorities from Great Britain and others from the Royal University whose mission is about to start its work. the Welfare State; (2) to supply a training ground at home for future leaders; (3) to raise a class of skilled technicians which will stimulate industry in Malta and produce more types of would-be emigrants who would be most welcome in other lands-because, in this thickly populated area, emigration is of prime importance.

It is clear that training for leadership is out of the question until there is a sixth-form system as a regular source of high-grade students for the University, and on the technical side, the proposed poly. technic will play an important part.

One of the most difficult problems to face in this connexion is the fact that Malta cannot at present provide its own secondary school teachers having the desirable academic qualifications. 'Therefore, to make the country self-sufficient, a good teaching staff must be a priority target, for the Report states that the salaries are adequate.

A Director of Technical Education has been appointed, because the present Government's plans for technical education are ambitious-and rightly so if Malta is to develop industries of her own and produce emigrants who are able to qualify for membership of the craft unions in Great Britain, Australia or the United States. The proposed polytechnic will provide for whole-time courses, 'sandwich' courses and a large range of continuation classes. At first, examinations in this institute will be for the national certificates, City and Guilds diplomas, and membership of the various engineering institutions ; eventually degrees courses in the polytechnic might be instituted. It is significant that the Dockyard Authorities are anxious that skilled workers for new industries in Malta should be trained outside the Dockyard, for they have no wish to hold a monopoly in this sort of education.

Mr. Crichton-Miller expresses the opinion that the considerable educational developments in Malta have already gone far in the right direction and the future standards aimed at are commendably high. But he qualifies this by emphasizing : the marked deficiency on the academic side and the need for reform in the University ; the rather indefinite aspirations governing the rapid development of technical education, and the obvious risk involved in training craftsmen for whom there is, at present, no suitable work ; the need for a more convincing effort to show that this great expansion in the educational services has not been done too hurriedly. He concludes his Report, however, as follows: ". . . when the foundations are so good, and the design so promising, the eritic is inclined to judge by the highest standard. This is the best tribute I can pay to those who have worked so hard, and with such vision, during these last two years"

\section{THE INSTITUTION OF CHEMICAL ENGINEERS}

\section{ROYAL CHARTER}

$\mathrm{T}$ $\mathrm{HE}$ foundation of the Institution of Chemical Engineers in 1922 was inspired by the experiences of the First World War. By the beginning of this century, Britain had fallen behind other countries, notably Germany, in the development of heavv 